\title{
DESIGN AND MANUFACTURING OF SCREW-EXTRUDER BASED BRIQUETTING MACHINE FOR AGRICULTURAL RESIDUES
}

\author{
A. M. El-Sheikha*
}

\begin{abstract}
A Screw-extruder based briquetting machine was developed, manufactured and tested for the utilization of two common different agricultural residues i.e. rice straw and cotton stalks. The manufactured briquetting machine consisted of two major parts. First part is a cutting and crushing unit which receives raw materials from a hopper located above the unit and working based on rotating disc carrying six sets of rectangular blades. Each set has four blades joined together from one side as one unit and rotating with free motion or relatively adjustable with each other. Second part is a pressing and extrusion system which was fixed down the cutting and crushing unit on a metal base has rectangular frame of $1600 \times 950 \mathrm{~mm}$. Cut and crushed material is being transferred by delivering cone to pressing and extruder system through a conical opening with net having specific diameter of mesh to pass only desired particles sizes. An electrical motor with reduction unit used to provide the machine with required power. The experiments carried out during 2013-2014. The machine has been tested with constant compression ratio, die dimensions and ratio of the screw volume utilization at the feeder area. Study variables were; two residues (rice straw and cotton stalks), four material moisture levels of mixed materials (25, 30, 45 and $40 \%$ ), and three bending material percentages 2, 4, $6 \%$ of residue raw material. Moisture content was measured and adjusted to be at the required level before starting the process of briquetting. Produced briquettes with different moisture content tested against their stability and durability and their densities and producing time have been recorded. Results showed that briquettes produced by screw-press based briquetting machine are hard enough to be transported when get treated at moisture content of 30 and $35 \%$. More shattered pieces were observed at lower moisture content of $25 \%$. In addition, in both residue types,
\end{abstract}

\footnotetext{
*Assistant Professor, Agric. Eng. Dept., Faculty of Agric., Damietta University
} 
adding more bender led to higher impact resistance (IRI). Sufficient production rate of briquettes have been obtained at $30 \%$ moisture content, where, production rates were 120.33, 128.67, $132.67 \mathrm{~kg} / \mathrm{h}$ for rice straw mixed with 2, 4 and 6 percent of bending material respectively and for cotton stalks, the production rates were 119.00, 123.33, and $131.33 \mathrm{~kg} / \mathrm{h}$ with 2, 4 and 6 percent of bending material respectively. However, higher moisture contents of 35 and $40 \%$ lead to lower production rate. Adding more bending material to the mixture resulted to more density for both rice straw and cotton stalks material and released briquettes with higher moisture content gave higher density.

Keywords: Briquetting machine, screw-extruder, rice straw, cotton stalks, density, durability.

\section{INTRODUCTION}

gricultural residues are usually bulky material and have low
densities which make their transportation uneconomical process
and their usage is limited.And thus it is difficult to efficiently handle large quantities of most feedstock and agricultural residues. Besides, the expenses are incurred during material handling and it is being costly to transport such materials (Kumar et al., 2003).One option of densification such materials is the use of briquetting process, which may be define as the process of compaction of residues into a product of higher density than the original raw material (Bhattacharya, 2002).Many works on development of biomass briquettes have been done from various types of biomass wastes, such as rise husk (Patabang, 2012), and paper pulp (Yaman et al., 2001). Generally, briquetting machines used in the briquetting of the agricultural residues are divided into three types depending on the die pressure range; the first type is the high pressure machines where the pressure reaches values more than $100 \mathrm{MPa}$ where the temperature rises to about $200-250^{\circ} \mathrm{C}$, which is sufficient to fuse the lignin content of the residue. Second type of machines is the medium pressure machines, with a pressure ranges between 5 to $100 \mathrm{MPa}$, which results in lower heat generation with the need to use additional heat source to melt the internal lignin content. The third type is the low pressure machines that work at pressure less than $5 \mathrm{MPa}$ in ambient 
temperature and requires additional binding material (Abakr and Abasaeed, 2006). There are several methods available for briquetting biomass, however, Bhattacharya et al. (2002) sated that in developing countries, the well-known briquetting method that is suitable for smallscale applications is the screw-press briquetting. This process can produce denser and stronger briquettes compared with piston presses. Wessapan et al. (2010) designed and developed a compact screw-press briquetting machine which combines three functions including crushing, mixing and briquetting in a single unit. The machine helpedin reducing cost and production time, and improving productivity. As many factors affecting the briquetting process, Demirbas and Sahin (1998) stated that highdensity products are desirable in terms of transportation, storage and handling and for briquette quality control, the physical parameters such as density, moisture content and compressive strength were found to be the best indicators of additive quality. Many tests have demonstrated that residues as wheat straw can be compressed to a relatively high density without binder and reaches 10 times that of normal bales but that process need application of pressures between 200-600 MPa after heating to a temperature of 76 to $126 \mathrm{C}^{\circ}$. However other straw residues like rice straw and cotton stalks didn't come under enough investigation either to use recommended mechanism could density them to get well-form briquettes or better operational condition to follow. So, the main objective of this study is to develop, manufacture and test a briquetting machine for the utilization of two common different agricultural residues(rice straw and cotton stalks) by using press screw- extruder with heated die mechanism (thermo-electrical element surrounding the die to reduce the moisture when briquettes material reaches the die cylinder).

\section{Briquetting machine}

\section{MATERIALS AND METHODS}

The manufactured briquetting machine consisted of two main units; the first including cutting and crushing unit; and pressing-extrusion system as second main unit. Cutting and crushing unit receives raw materials from a hopper located above the unit. Cut and crushed material is being transferred by delivering cone to pressing and extruder system through a conical opening with net having specific diameter of mesh to pass only 
desired particles sizes. The pressing and extrusion system fixed below the cutting and crushing unit on a metal base has rectangular frame of $1600 \mathrm{x}$ $950 \mathrm{~mm}$. electrical motor which provide the machine with required power and its transmission with reduction unit links had an extended metal frame to hold them. Technical drawing and main component of manufactured briquetting machine are shown in Fig 1.

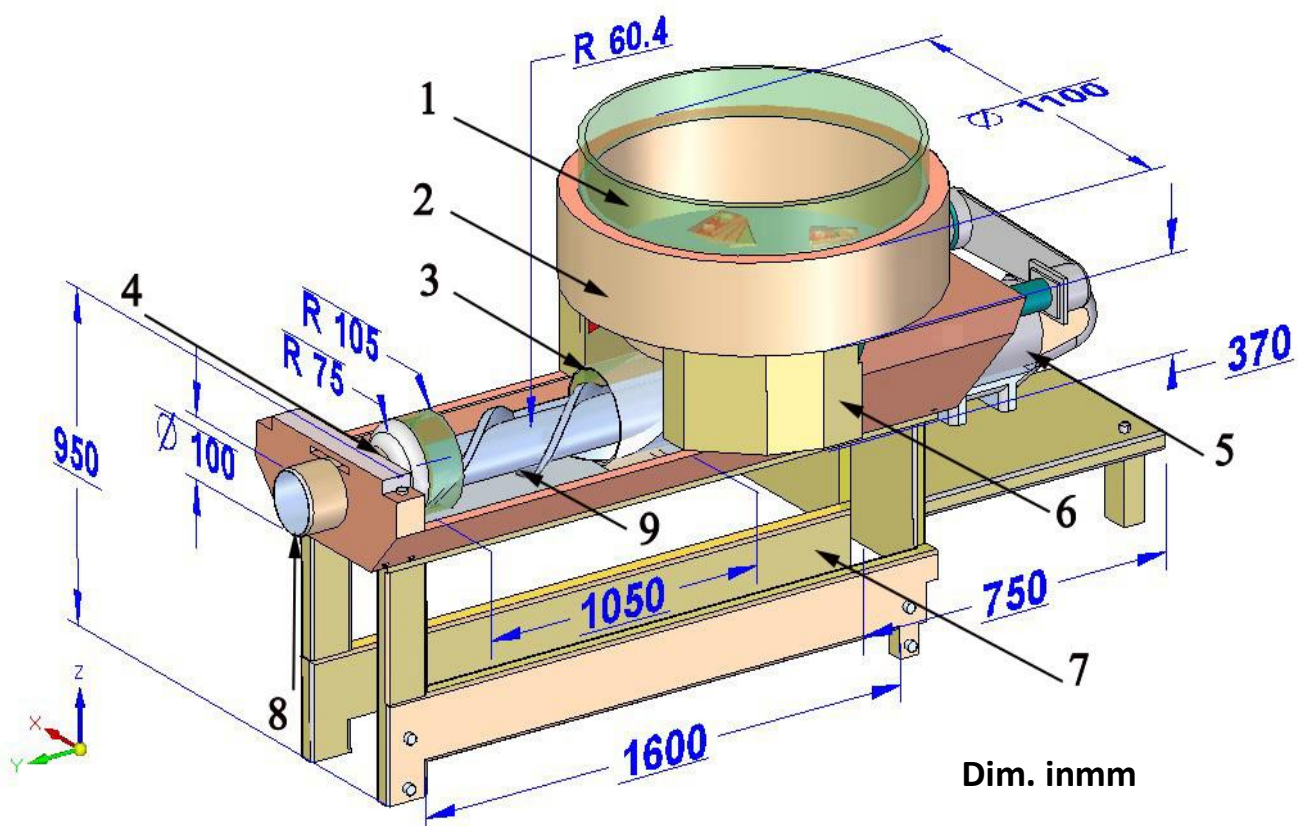

Fig.1 Briquetting machine and its components 1) Hopper 2) Cutting, crushing unit 3) Pressing and extrusion system 4) Die cylinder 5) Electrical motor 6) Outer surface of delivering cone 7) Main frame8) Briquettes outlet 9) Screw.

\subsection{Cutting and crushing unit}

For cutting and crushing agricultural residues, a rotating disc carrying six sets of rectangular blades has been used. Each set has four blades joined together from one side as one unit and rotating with free motion or relatively adjustable with each other. $180 \times 8 \mathrm{~mm}$ section steel blades have been used with sharpening their edge (Fig.2). Distance from rotating disc to outer cutting unit wall set to allow small size particles to fall into the conical opening and net which located under the cutting unit by 15 
mm. The other un-cut materials remain on rotating disc till cut (Fig. 3). Blinder materials added manually for each batch to control the required amount as experimental purpose, but a mixing unit can be attached for further investigations with the machines. Maximum lump sizes (length) produced by cutting and crushing unit were 9.9 and $9 \mathrm{~mm}$ for cotton stalks and rice straw respectively.

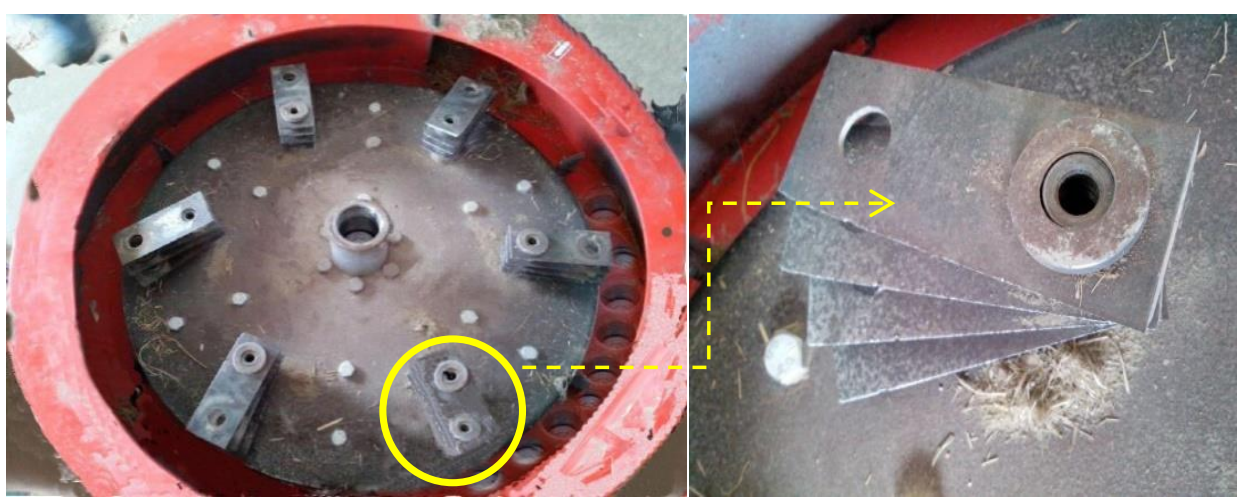

Fig.2 Cutting and crushing unit with blades sets.
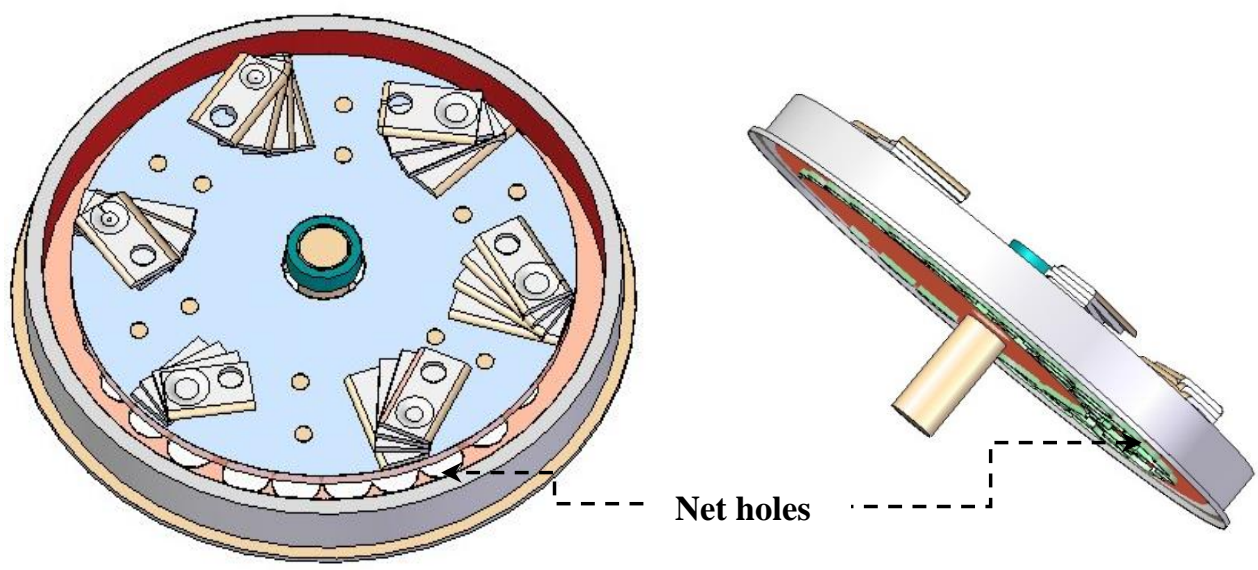

Fig.3 Arrangement of net under cutting and crushing unit.

\subsection{Pressing and extrusion system}

Material is pressed and extruded by a $0.55 \%$ carbon steel trapezoidal screw extruder $1050 \mathrm{~mm}$ in length and $60.4 \mathrm{~mm}$ radius, it acts as a continuous feeder with $130.5 \mathrm{rpm}$ and using short screw pitch and driven 
by $5 \mathrm{hp}$ electrical motor supported by two end bearings and intermediate bearings. The material is moved forward along the axis of the trough by the thrust of screw thread and flight. Volume of the material is decreased at the end portion of the extruder and it is transferred from cutting and mixing unit to the die exit to have $100 \mathrm{~mm}$ diameter of briquettes and flexible on length. This is achieved by decreasing closed trough diameter, from 210 to $100 \mathrm{~mm}$ at the end point with a uniform diameter at the feeding position. To determine different parameters needed to manufacture the screw pressing unit, standard procedure of design and testing such types of screw press have been used (Shigley et al.,2004; Khurmi and Gupta, 2005; Kulinowski and Kasza, 2012; Conveyoreng. 2012)

\subsubsection{Radial clearance}

Required radial clearance can determine by multiplying the class ratio by product max lump size (length, $\mathrm{mm}$ ), where class ratio is one of three different classes 1, 2, and 3 can be found according to the percentage of lumps in the mixture. In the study case, class 3 has been chosen where a mixture of lumps of which $95 \%$ or more are lumps ranging from maximum size to one half of the maximum size; and $5 \%$ or less are lumps less than one tenth of the maximum size. In this case class ratio $=4.50$, then:

Required radial clearance $=4.5 \times 9.9=44.55 \mathrm{~mm}$ (is taken as $44.6 \mathrm{~mm}$ )

\subsubsection{Screw speed and length}

For the calculation of screw speed, where special types of screws in this study was used, (short pitch) with cut and folded flight with uniform mixing paddle, an equivalent required capacity must be used,. The equivalent capacity is found by multiplying the required capacity by one or more of the capacity factors that are involved, e.g. special screw pitch capacity factor $\mathrm{cf}_{1}=1.5$ in case of screw pitch $=2 / 3$ diameter of screw, special screw ribbon flight modification capacity factor $\mathrm{cf}_{2}=1.62$.

To calculate required equivalent capacity, feeding rate was set to be from $20 \mathrm{~kg}$ to $200 \mathrm{~kg}$ per hour as recommended for residue feeding rate and will vary according to moisture and the nature of feeding mixture. 
Dividing feeding rate by material density gave the required capacity (volumetric capacity) to be from 0.18 to $1.18 \mathrm{~m}^{3} / \mathrm{hr}$ for cotton stalks and from 0.11 to $1.12 \mathrm{~m}^{3} / \mathrm{h}$ for rice straw material. So; Minimum equivalent capacity $\left(\mathrm{m}^{3} / \mathrm{h}\right)$ for cotton stalk material $=$

Required capacity $\times \mathrm{CF}_{1} \times \mathrm{CF}_{2}=0.18 \times 1.5 \times 1.62=0.48 \mathrm{~m}^{3} / \mathrm{h}$.

Maximum equivalent capacity $\left(\mathrm{m}^{3} / \mathrm{h}\right)$ for cotton stalk material $=$

Required capacity $\times \mathrm{CF}_{1} \times \mathrm{CF}_{2}=1.18 \times 1.5 \times 1.62=2.87 \mathrm{~m}^{3} / \mathrm{h}$.

Minimum equivalent capacity $\left(\mathrm{m}^{3} / \mathrm{h}\right)$ for rice straw material=

Required capacity $\times \mathrm{CF}_{1} \times \mathrm{CF}_{2}=0.11 \times 1.5 \times 1.62=0.27 \mathrm{~m}^{3} / \mathrm{h}$.

Maximum equivalent capacity $\left(\mathrm{m}^{3} / \mathrm{h}\right)$ for rice straw material $=$

Required capacity $\times \mathrm{CF}_{1} \times \mathrm{CF}_{2}=1.12 \times 1.5 \times 1.62=2.72 \mathrm{~m}^{3} / \mathrm{h}$.

Considering percent closed trough load as $45 \%, 1 \mathrm{rpm}$ volumetric capacity $\left(\mathrm{m}^{3} / \mathrm{h}\right)=0.022$, then:

Minimum Screw speed for cotton stalk material $=$

Equivalent capacity $\left(\mathrm{m}^{3} / \mathrm{h}\right) / 1 \mathrm{rpm}$ capacity $\left(\mathrm{m}^{3} / \mathrm{h}\right)$

$=0.48 / 0.022=21.8 \mathrm{rpm}$.

Maximum screw speed for cotton stalk material $=$

Equivalent capacity $\left(\mathrm{m}^{3} / \mathrm{h}\right) / 1 \mathrm{rpm}$ capacity $\left(\mathrm{m}^{3} / \mathrm{h}\right)$

$=2.87 / 00.022=130.5 \mathrm{rpm}$.

Minimum screw speed for rice straw material $=$

Equivalent capacity $\left(\mathrm{m}^{3} / \mathrm{h}\right) / 1 \mathrm{rpm}$ capacity $\left(\mathrm{m}^{3} / \mathrm{h}\right)$

$=0.27 / 0.022=12.3 \mathrm{rpm}$.

Maximum screw speed for rice straw material $=$

Equivalent capacity $\left(\mathrm{m}^{3} / \mathrm{h}\right) / 1 \mathrm{rpm}$ capacity $\left(\mathrm{m}^{3} / \mathrm{h}\right)$

$=2.72 / 0.022=123.6 \mathrm{rpm}$.

According to maximum required speed,130.5 rpm will be considered as design speed of the screw. The length of the screw to retain the material for the specified mixing time (retention time assumed to be 4 second as maximum screw speed is $130.5 \mathrm{rpm}$ ) is calculated as follows:

$\mathrm{L}=\mathrm{N} \times$ length of pitch $\times$ time $=130.5 \times 2 / 3(0.19) \times 4 / 60=1.1 \mathrm{~m}$, then screw with length of 1.1 meter to be used (reduced to $1.05 \mathrm{~m}$ in actual installation). Final specifications of manufactured screw extruder are listed in Table 1 and Fig.4. 


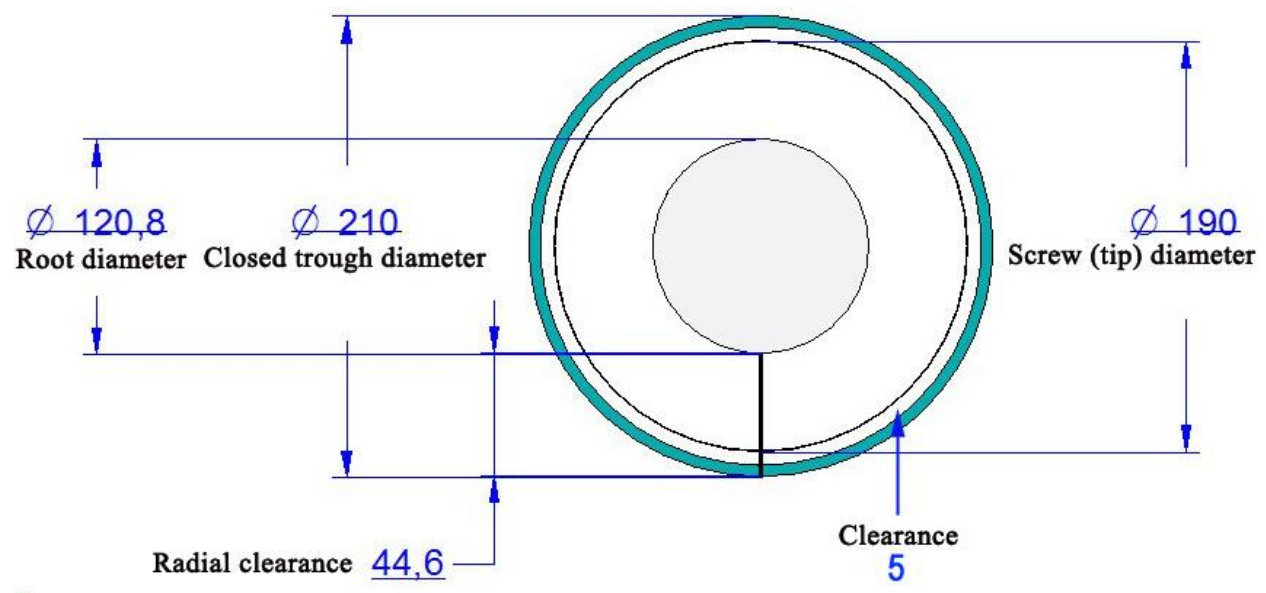

Fig. 4Dimensions of designed extruder screw

Table 1: Specification of manufactured screw extruder

\begin{tabular}{|l|c|l|c|}
\hline \multicolumn{1}{|c|}{ Specification } & Value & \multicolumn{1}{|c|}{ Specification } & Value \\
\hline Material & $\begin{array}{c}0.55 \% \\
\text { Carbon steel } \\
\text { normalized }\end{array}$ & $\begin{array}{l}\text { Normal power rate, } \\
\text { W (hp) }\end{array}$ & $\begin{array}{c}2830 \\
(3.76)\end{array}$ \\
\hline Surface stress factor & 15.2 & $\begin{array}{l}\text { Screw speed, } \\
\text { revolution per } \\
\text { minute }\end{array}$ & 130.5 \\
\hline $\begin{array}{l}\text { Bending stress } \\
\text { factor }\end{array}$ & 17.3 & Helix angel, deg. & 22 \\
\hline $\begin{array}{l}\text { Ultimate tensile } \\
\text { stress, MPa }\end{array}$ & 270 & $\begin{array}{l}\text { Average material } \\
\text { channel depth (both } \\
\text { sides), mm }\end{array}$ & 81.2 \\
\hline $\begin{array}{l}\text { Screw (tip) } \\
\text { diameter, mm }\end{array}$ & 190 & $\begin{array}{l}\text { Screw diameter } \\
\text { factor }\end{array}$ & 0.4 \\
\hline Root diameter, mm & 120.8 & Lead angel, deg. & 3.29 \\
\hline $\begin{array}{l}\text { Closed trough } \\
\text { diameter, mm }\end{array}$ & 210 & Clearance, mm & 5 \\
\hline $\begin{array}{l}\text { Radial clearance, } \\
\text { mm }\end{array}$ & 44.6 & Screw length, mm & 1050 \\
\hline
\end{tabular}




\section{Study variables and measurements}

\subsection{Crop residues}

Two crop residues have been choose rice straw and cotton stalks. Both residues are available in big amounts within farmers' fields and easy to find with required amounts. The available residues have lower moisture content and mostly found in dry conditions. From pre-testing of the machine, using such straw in their original moisture contents and in ambient air is very difficult for briquetting. So, bender material has been used to insure favorable forming of produced briquettes Characteristics (physical and mechanical properties) of used crop residue listed in table, stem length, stem diameter and moisture content were measured and the other noted according to AmerEissa et al. (2008); Morsy (2011), and Zhang et al. (2012). For cotton stalksand even with the high number of blades attached to cutting and crashing unit, it is important to divide the normal length into smaller parts to fit the hoper as it is lengthy compared to the rice straw.

Table 2: Physical and mechanical properties of used crop residues

\begin{tabular}{|l|c|c|}
\hline \multicolumn{1}{|c|}{ Characteristic } & Cotton stalks & Rice straw \\
\hline Stem length, mm & From 980 to 1820 & $\begin{array}{c}\text { Normal length from } 840 \\
\text { to } 970, \text { after combine } \\
\text { harvester from } 300 \text { to } 450\end{array}$ \\
\hline Stem diameter, mm & From 7.3 to 15 & From 2 to 3.9 \\
\hline Mass of stalk, $\mathbf{g}$ & From 35 to 200 & From 12 to 65 \\
\hline Moisture content, \% & From 11.15 to 21.9 & From 6.58 to11.92 \\
\hline Tensile strength, MPa & 11.54 to 26.5 & From 29 to 47 \\
\hline Compressive strength, MPa & 6.1 to 16.75 & 8 to 12 \\
\hline Bulk density, kg/m $\mathbf{3}$ & $\begin{array}{c}160 \text { to } 180 \\
\text { (average } 170)\end{array}$ \\
\hline Max lump size, $\mathbf{~ m m ~}$ & 10 & 178.39 ) \\
\hline
\end{tabular}




\subsection{Variables and measurements}

The machine has been tested with constant compression ratio, die dimensions and ratio of the screw volume utilization at the feeder area. Study variables were; two residues (rice straw and cotton stalks, four material moisture levels of mixed materials $(25,30,45$ and $40 \%$ ), and bender material percentages (starch) 2, 4, $6 \%$ of residue raw material. Moisture content was measured and adjusted to be at the required level before starting the process of briquetting by measuring a sample of raw materials with bender material percentage and adding amount of water to increase the moisture percentage when the mixture does not reach it Produced briquettes (Fig.5) with different moisture content tested against their stability and durability by applying drop test as suggested by Pryor (1988) and Nalladurai and Morey(2006), where we dry the briquettes for at least 96 hours and drop the samples from a height of 2 meters onto a concrete floor to record the number of broken briquette pieces with disregarding the pieces which weighed less than $5 \%$ of the initial weight After 10 drops for each briquette, the impact resistance index (IRI) is calculated as follows (Equation 1) :

$$
\text { IRI }=\frac{\mathbf{N}}{\mathbf{n}} \times 100
$$

Where, $\mathrm{N}=$ number of drops, and

$\mathrm{n}=$ total number of pieces weighing more than $5 \%$ of the initial weight.

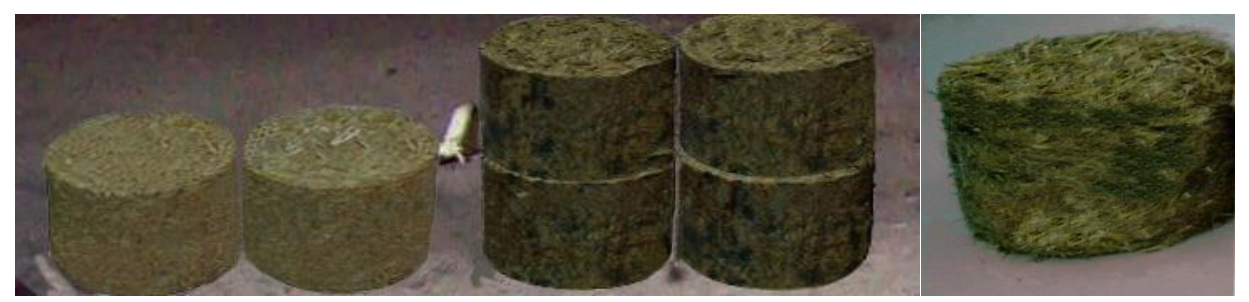

Well-formed briquettes

Deformed briquettes

Fig.5 Briquettes produced by briquetting machine

Densities of briquettes are obtained by measuring the weight and volume of briquettes during the production and before drying to address the effect of moisture level of mixture, mixing percentage of binder, and material type on densification values. Heat was applied externally by means of 
thermo-electrical element surrounding the die to reduce the moisture when briquettes material reaches the die cylinder and just before obtaining the briquettes. Temperature degree was fixed under all other variable and measured by means of a thermocouple. Extruded materials in form of briquettes are being received on a table, at desirable required length and with a force applied by hand-push, the briquettes cab be disconnected easily from the die cylinder (Fig. 6)

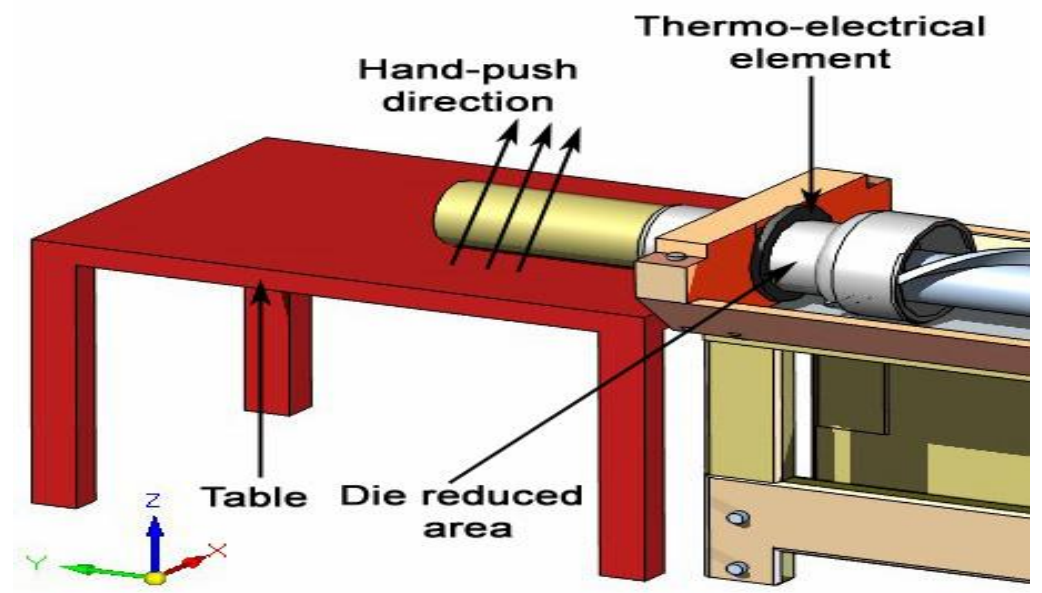

Fig.6Mechanism of disconnecting briquettes from die cylinder

Weights of produced briquettes noted immediately with their production time and again after four days to calculate the production rate and density when the briquettes are being suitable for transportation a statistical software program has been used for data modeling and analysis of variances.

\section{RESULT AND DISCUSSION}

\section{Durability of briquetted residues}

Durability is a measure of the briquette's resistance to mechanical action during handling and transporting. It is difficult to give an acceptable value for the impact resistance index (IRI) as the relationship between test results and actual experience has not been established. However, it was observed that briquettes produced by screw-presses based briquetting machine are hard enough to be transported when get treated at moisture content of 30 and $35 \%$. More shattered pieces were observed at lower moisture content of $25 \%$ and also at higher moisture value of $40 \%$. In 
both residue types adding more bender led to higher impact resistance (IRI). The value of IRI increased by 27.6 and $66.7 \%$ when the bender percentage increased from 2 to $4 \%$ and from 2 to $6 \%$ respectively for rice straw at $30 \%$ moisture content. While, increasing bender percentage from 2 to $4 \%$ and from 2 to $6 \%$ increased the IRI for cotton stalks by 27.6 at moisture content of $30 \%$ (Fig.7 and Fig. 8).

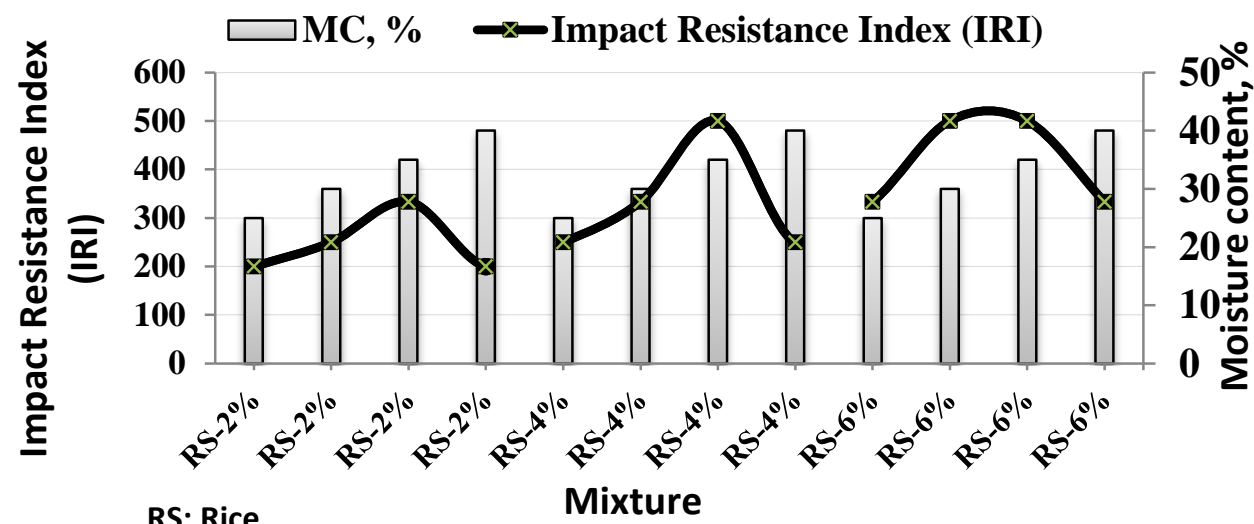

Fig.7Durability of briquetted rice straw at different moisture content with different bending material percentages

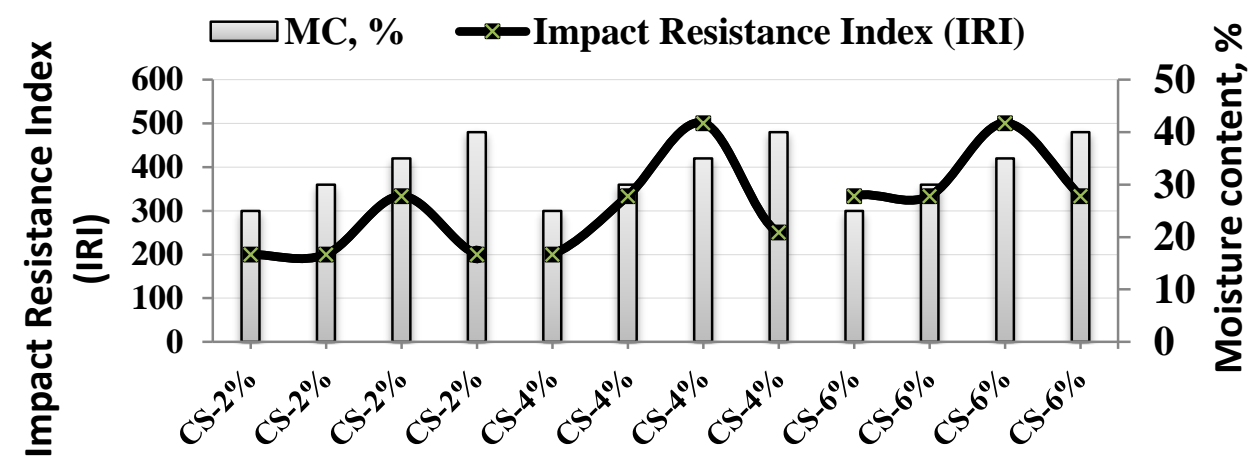

CS:Cotton stalks

Mixture

Fig. 8Durability of briquetted cotton stalks at different moisture content with different bending material percentages

Data modeling and analysis of variances showed the significances of both the bender percentage and mixture moisture content on IRI with standard division of 106.728. Interaction between factors mixture and MC \% confirmed data trend is presented in Fig. 9. 


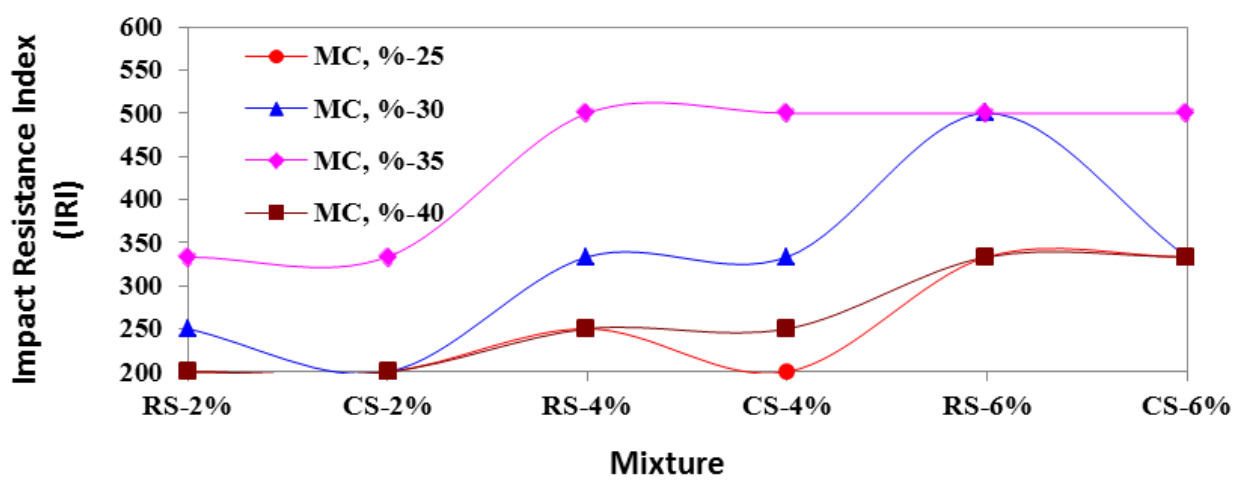

Fig.9 Interaction between factors mixture and MC, \%

\section{Production rate}

In general, best production rates were found at $30 \%$ moisture content. Where, production rates were $120.33,128.67,132.67 \mathrm{~kg} / \mathrm{h}$ for rice straw mixed with 2, 4 and 6 percent of bending material respectively. For cotton stalks, the production rates at $30 \%$ moisture content were $119.00,123.33$, and $131.33 \mathrm{~kg} / \mathrm{h}$ with 2,4 and 6 percent of bending material respectively. Also, it was clear that production rates increase with increasing the bending material percentage (Fig.10, Fig. 11, and Fig.12). Lower moisture content of $25 \%$ resulted in lower production rates, where, the production rate decreased by $46.8,43.27$, and $6.29 \%$ when moisture content decreased in the mixture from 30 to $25 \%$ for rice straw material at 2,4 , and $6 \%$ of bending material percentage respectively. Same trend was obtained with using cotton stalks materials, where there was reduction in production rates by $57.14,48.65$, and $18.27 \%$ when moisture content decreased from 30 to $25 \%$ at 2,4 , and $6 \%$ of bending material percentage respectively. Lower production rates at lower moisture content may be due to the machine's frequent blockages at that level of moisture content compared to higher amount of water inside the mixture. Higher moisture contents of 35 and $40 \%$ lead to lower production rate too Production rate decreased by 22.44 and $54.57 \%$ when moisture content of rice straw mixture increased from 30 to 35 and from 30 to 40 $\%$ respectively at $2 \%$ bending material percentage. Also, for cotton stalks, production rate decreased by 17.37 and $60.78 \%$ when moisture content increased from 30 to 35 and from 30 to $40 \%$ respectively at $2 \%$ bending material percentage. 


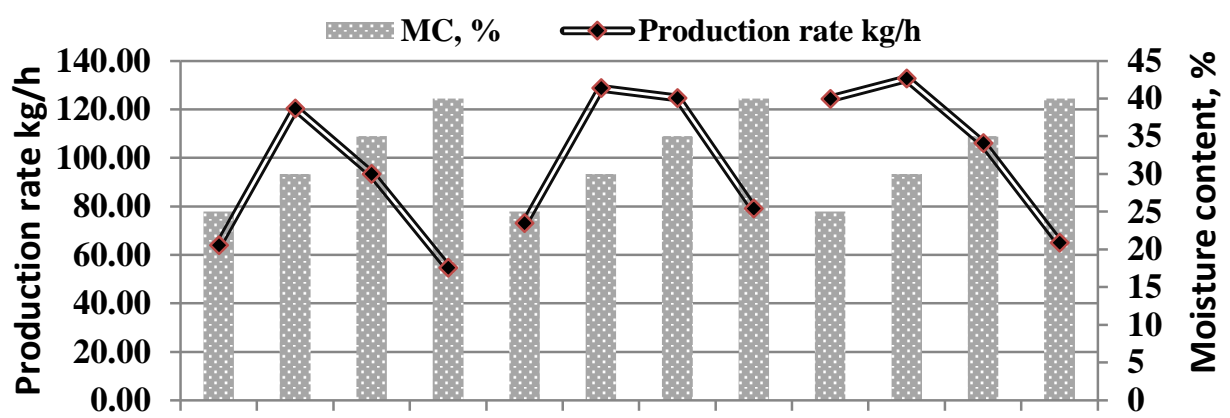

RS: Rice straw

Mixture

Fig.10 Production rate of briquetted rice strawat different moisture content with different bending material percentages

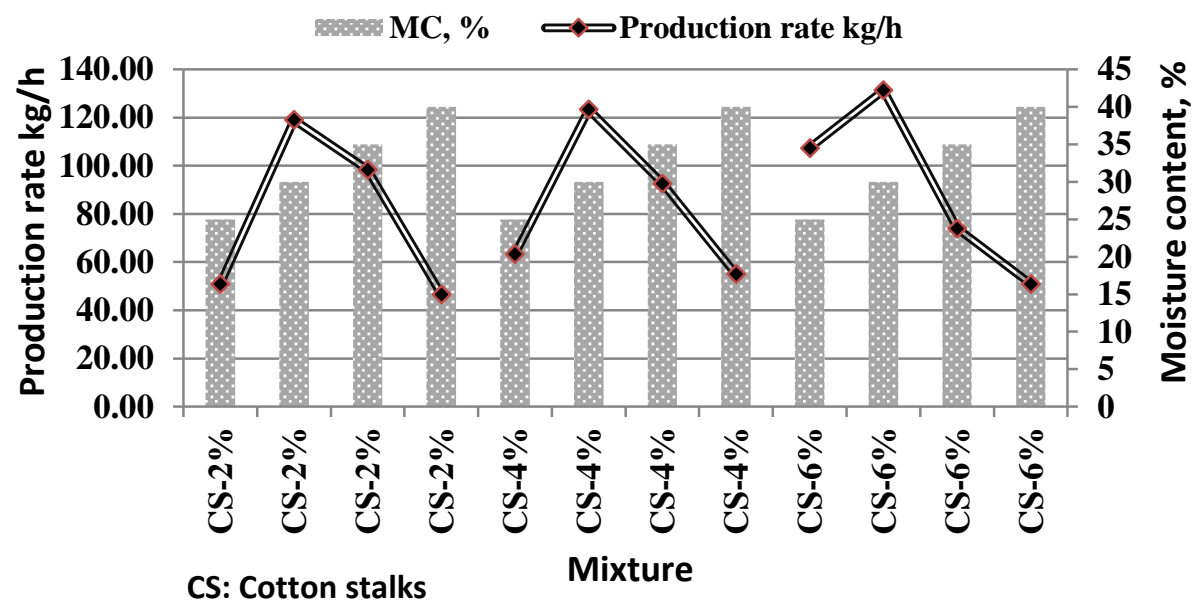

Fig. 11 Production rate of briquetted cotton stalks at different moisture content with different bending material percentages

In 4 and $6 \%$ bending percentage the production rates also decreased. Lower production rates at higher moisture contents happen because of the initial higher water content of the mixture and the losses in weight happen due to drying over the time. Data modeling and analysis of variances showed the significances of both the bender percentage and mixture moisture content on production rate with standard division of 30.455 . 


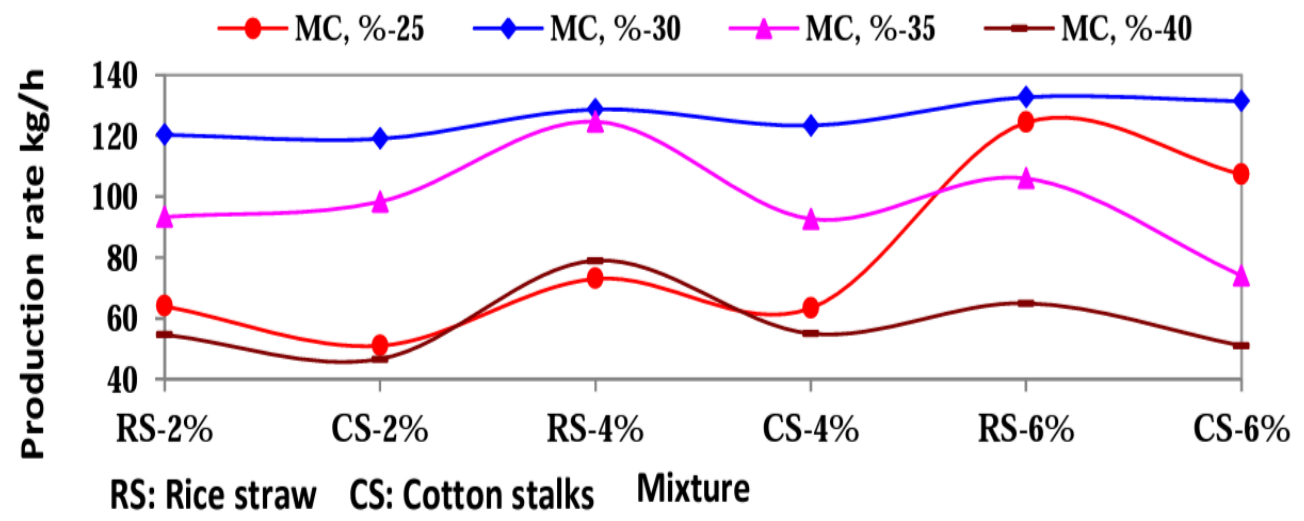

Fig.12 Fig. 12 Interaction between factors mixture and MC, \%

\section{Density}

Average density of produced briquettes ranged from 350.33 to $469.67 \mathrm{~kg} / \mathrm{m}^{3}$ (Fig. 13, Fig. 14,and Table 3). It was clear from data that adding more bending material to the mixture resulted to more density for both rice straw and cotton stalks material. Where increasing the percentage of bending material from 2 to $6 \%$ increased the density from $391.33417 .33 \mathrm{~kg} / \mathrm{m}^{3}$ and from 371.33 to $395.33 \mathrm{~kg} / \mathrm{m}^{3}$ for rice straw and cotton stalk material respectively at $30 \%$ moisture content.

Table 3: densities of produced briquettes at different moisture content with different bending material percentages

\begin{tabular}{|c|c|c|c|c|c|c|c|c|}
\hline \multirow[b]{2}{*}{ Material } & \multicolumn{2}{|c|}{ Bender , $2 \%$} & & \multicolumn{2}{|c|}{ Bender , $4 \%$} & & \multicolumn{2}{|c|}{ Bender, $6 \%$} \\
\hline & $\underset{\%}{\mathrm{MC}}$ & $\begin{array}{c}\text { Density, } \\
\mathrm{Kg} / \mathrm{m}^{3}\end{array}$ & & $\underset{\%}{\mathrm{MC}}$ & $\begin{array}{c}\text { Densit } \\
\mathbf{y}, \\
\mathbf{K g} / \mathbf{m}^{3}\end{array}$ & & $\underset{\%}{\mathrm{MC}}$ & $\begin{array}{c}\text { Density. } \\
\mathrm{Kg} / \mathrm{m}^{3}\end{array}$ \\
\hline \multirow{4}{*}{$\mathbf{R S}$} & 25.00 & 376.33 & \multirow{4}{*}{$\mathbf{R S}$} & 25.00 & 386.00 & \multirow{4}{*}{$\mathbf{R S}$} & 25.00 & 398.00 \\
\hline & 30.00 & 391.33 & & 30.00 & 401.00 & & 30.00 & 417.33 \\
\hline & 35.00 & 422.67 & & 35.00 & 418.33 & & 35.00 & 438.00 \\
\hline & 40.00 & 435.00 & & 40.00 & 453.33 & & 40.00 & 469.67 \\
\hline \multirow{4}{*}{ CS } & 25.00 & 350.33 & \multirow{4}{*}{ CS } & 25.00 & 369.00 & \multirow{4}{*}{ CS } & 25.00 & 380.00 \\
\hline & 30.00 & 371.33 & & 30.00 & 386.00 & & 30.00 & 395.33 \\
\hline & 35.00 & 406.00 & & 35.00 & 418.67 & & 35.00 & 420.33 \\
\hline & 40.00 & 420.00 & & 40.00 & 443.00 & & 40.00 & 439.67 \\
\hline
\end{tabular}




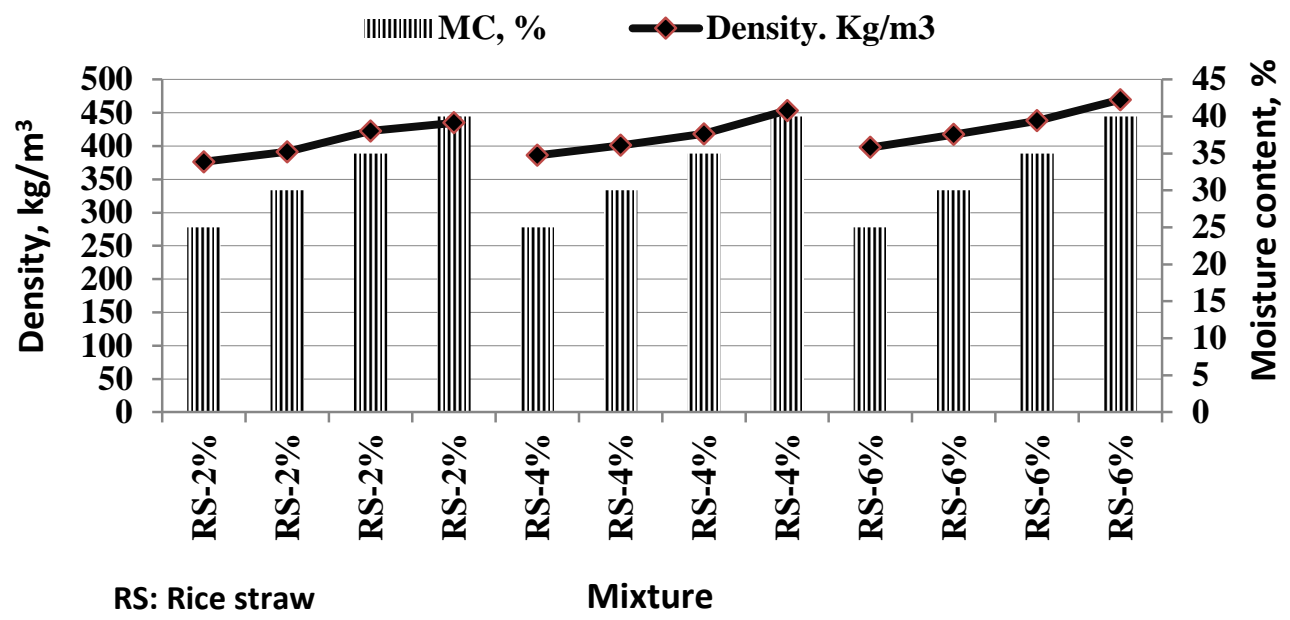

Fig.13 Densities of produced rice straw briquettes at different moisture content with different bending material percentages

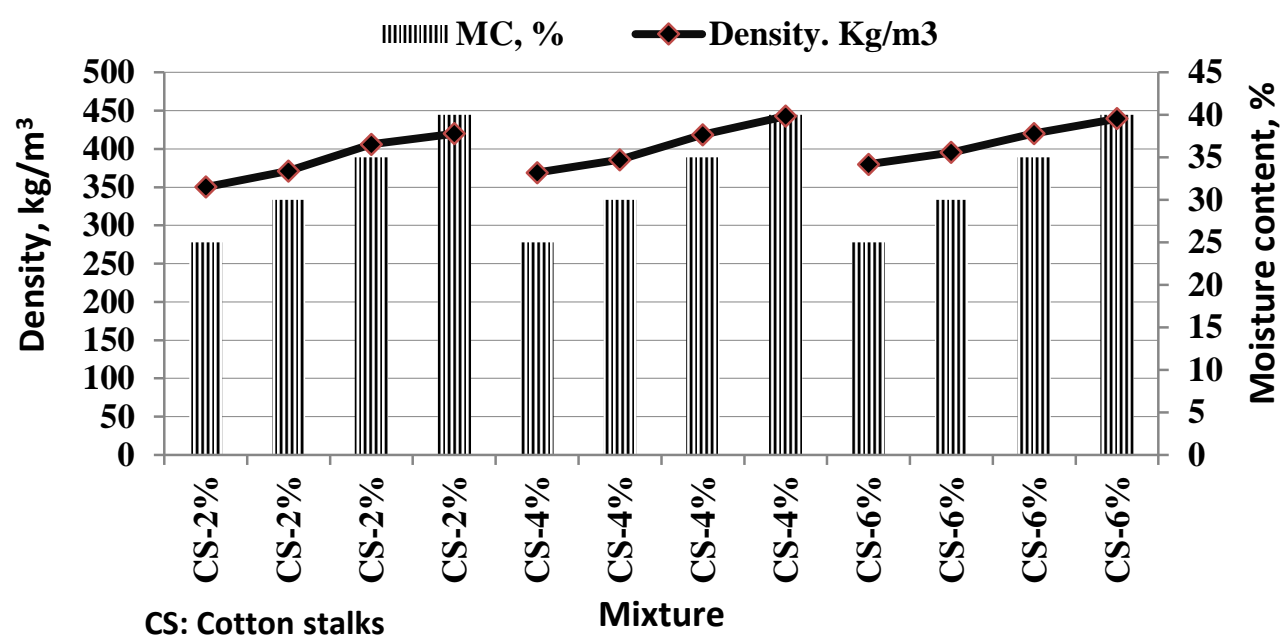

Fig.14 Densities of produced cotton stalks briquettes at different moisture content with different bending material percentages

That may be because of the fine form of the used bending material. Released briquettes with higher moisture content gave higher density, where, increasing moisture content from 25 to $40 \%$ increased the produced briquettes density from 376.33 to $435 \mathrm{~kg} / \mathrm{m}^{3}$ and from 350.33 to $420.00 \mathrm{~kg} / \mathrm{m}^{3}$ for rice straw and cotton stalks respectively at $2 \%$ of bender. Same trend of increasing densities obtained at 4 and $6 \%$ of 
bending material. That maybe of because of the higher water content inside the mixture, that trend is logic, however, the higher moisture content tended to make deformed briquettes after drying. Data modeling and analysis of variances showed the significances of both the bender percentage and mixture moisture content on production rate with standard division of 29.419 .

\section{Cost analysis}

In cost analysis, both rice straw and cotton stalks which used as raw materials, are available free of cost in farmers' fields and in dry form and do not require drying prior to briquetting. The cost correlated to the residues is the cost of collection and transportation. The cost of the binding material is critical to the economic success of the machine, so the smallest amount of binder necessary for an acceptable briquette should be used. In cost analysis for residue briquettes production by using briquetting machine and one labor, it is assumed that the briquetting machine have a useful life expectancy of 5 years, the operating time at 8 hours a day, 250 days in a year, direct labor cost per day is 60 L.E, electricity cost of 0.144 L.E. $/ \mathrm{kWh}$, total electrical input power is $2.83 \mathrm{~kW}(3.76 \mathrm{hp}$ for screw extruder) and $0.65 \mathrm{Kw}(0.87 \mathrm{hp}$ for cutting and crushing unit and for the heater). So, Energy consumption cost can be calculated as per day, per month and/or per year, by using below equations (Equations 2 and 3 ) for daily cost, the Electricity cost per day is 4 L.E. / day:

$$
\begin{aligned}
& E_{(k W h / d a y)}=P_{(W)} \times t_{(h / d a y)} / 1000(W / k W) \ldots \ldots \ldots \ldots \ldots \text { (2) } \\
& \operatorname{Cost}(E . P / \text { day })=E_{(k W h / d a y)} \times \operatorname{Cost}(E . P . / k W h) \ldots \ldots \ldots \ldots \ldots(3)
\end{aligned}
$$

Where:

E: Electrical input power per day.

Depending on the added bender amounts, labor cost and electrical cost per day, the below table presented the cost against the production rate in daily bases (Table 4). 
Table 4 Cost against the production rate in daily bases

\begin{tabular}{|l|c|c|c|c|c|c|}
\hline Mixture & $\begin{array}{c}\text { MC } \\
\text { \% }\end{array}$ & $\begin{array}{c}\text { Production } \\
\text { rate kg/day }\end{array}$ & $\begin{array}{c}\text { Electricity } \\
\text { cost L.E. / } \\
\text { day }\end{array}$ & $\begin{array}{c}\text { Bender } \\
\text { cost, } \\
\text { L.E. }\end{array}$ & $\begin{array}{c}\text { labor } \\
\text { cost L.E } \\
\text { /day }\end{array}$ & $\begin{array}{c}\text { Total } \\
\text { cost, L.E } \\
\text { /day }\end{array}$ \\
\hline RS-2\% & 25 & 512.00 & 4 & 10.24 & 60 & 74.24 \\
\hline RS-2\% & 30 & 962.67 & 4 & 19.25 & 60 & 83.25 \\
\hline RS-2\% & 35 & 746.67 & 4 & 14.93 & 60 & 78.93 \\
\hline RS-2\% & 40 & 437.33 & 4 & 8.75 & 60 & 72.75 \\
\hline CS-2\% & 25 & 408.00 & 4 & 8.16 & 60 & 72.16 \\
\hline CS-2\% & 30 & 952.00 & 4 & 19.04 & 60 & 83.04 \\
\hline CS-2\% & 35 & 786.67 & 4 & 15.73 & 60 & 79.73 \\
\hline CS-2\% & 40 & 373.33 & 4 & 7.47 & 60 & 71.47 \\
\hline RS-4\% & 25 & 584.00 & 4 & 23.36 & 60 & 87.36 \\
\hline RS-4\% & 30 & 1029.33 & 4 & 41.17 & 60 & 105.17 \\
\hline RS-4\% & 35 & 997.33 & 4 & 39.89 & 60 & 103.89 \\
\hline RS-4\% & 40 & 632.00 & 4 & 25.28 & 60 & 89.28 \\
\hline CS-4\% & 25 & 506.67 & 4 & 20.27 & 60 & 84.27 \\
\hline CS-4\% & 30 & 986.67 & 4 & 39.47 & 60 & 103.47 \\
\hline CS-4\% & 35 & 741.33 & 4 & 29.65 & 60 & 93.65 \\
\hline CS-4\% & 40 & 440.00 & 4 & 17.60 & 60 & 81.60 \\
\hline RS-6\% & 25 & 994.67 & 4 & 59.68 & 60 & 123.68 \\
\hline RS-6\% & 30 & 1061.33 & 4 & 63.68 & 60 & 127.68 \\
\hline RS-6\% & 35 & 848.00 & 4 & 50.88 & 60 & 114.88 \\
\hline RS-6\% & 40 & 520.00 & 4 & 31.20 & 60 & 95.20 \\
\hline CS-6\% & 25 & 858.67 & 4 & 51.52 & 60 & 115.52 \\
\hline CS-6\% & 30 & 1050.67 & 4 & 63.04 & 60 & 127.04 \\
\hline CS-6\% & 35 & 592.00 & 4 & 35.52 & 60 & 99.52 \\
\hline CS-6\% & 40 & 408.00 & 4 & 24.48 & 60 & 88.48 \\
\hline RS-Rice & & 4 & & & & \\
\hline
\end{tabular}

\section{RS: Rice straw CS: Cotton stalks}

The cost does not include the collecting, transportation and maintenance of the machine, but it expresses only the operational cost of the machine with specified bender added amount. However, payback period for the production and benefits of the machine will depend on the price and uses of the briquettes.

\section{CONCLUSION}

The manufactured machine can work properly to produce briquettes with satisfied quality and in an acceptable range and dimensions. The 
briquettes can be transferred and easy to be handled as fodder or as a source for energy. It is possible to add a mechanical system for adding binder materials for other biomass production purposes. Briquetting waste papers, other crop residue and food wastes is another option to use such machine for more and widening productivity. Adding more bender led to higher impact resistance (IRI) but will increase the total cost as the bender cost is usually more expensive than the cost of the raw materials being briquetted. To obtain well-formed briquettes it is important to have mixture of $30 \%$ moisture content. Also, higher density is desirable in case of produced briquettes, but with the limit to prevent the deformation of excess water in the produced briquettes, One labor can operate the machine as feeding raw materials is being done and there is a time to observe the coming briquettes form the outlet before second batch. Hence the machine helps to reduce human power need, space for storage and transportation cost.

\section{REFERENCES}

Abakr, Y. A. and Abasaeed A. E. (2006). Experimental Evaluation of a Conical-Screw Briquetting Machine for the Briquetting of Carbonized Cotton Stalks in Sudan. Journal of Engineering Science and Technology 1(2):212-220.

AmerEissa A.H., Gomaa A.H., Baiomy M.H., and Ibrahim A. A. (2008). Physical and Mechanical Characteristicsfor Some Agricultural Residus.Misr J. Ag. Eng., 25(1): 121-146.

Bhattacharya, S.C. (2002). A Global Review with Emphasis on Developing Countries, paper presented in First World Pellets Conference, Stockholm, Sweden.

Bhattacharya, S. C., Augustus, L. M. and Rahman Md. M. (2002). A Study on Improved Biomass Briquetting, Energy for Sustainable Development, vol.6 (2): 67-71.

Conveyoreng (2012). Screw Conveyor components \& design. Version 2.20.Conveyor Engineering \& Manufacturing. 1345 76th Ave SW Cedar Rapids, IA 52404. USA. Available at: 
http://www.conveyoreng.com/wpcontent/uploads/downloads/2013/02/CEMC-Screw-ConveyorManual-2.20.pdf

Demirbas,A., and A. Sahin(1998). Evaluation of biomass residue:1. Briquetting waste paper and wheat straw mixtures.Fuel Processing Technology 55, 175-183.

Kulinowski, P., and Kasza, P. (2012).Screw conveyors. Department of Mining, Dressing and Transport Machines AGH.AGH University of Science and Technology.Poland. Available at:

http://www.kmg.agh.edu.pl/sites/default/files/pdf_ScrewConveyors_eng.p df

Khurmi, R.S. and Gupta J.K. (2005). Text Book of Machine Design.Chand (S.) \& Co Ltd, India; $25^{\text {th }}$ edition. ISBN-13: 9788121925372- 8121925371, 1230 pages.

Kumar, A., Cameron, J. B., Flynn P. C. (2003). Biomass power cost and optimum plant size in western Canada.Biomass and Bioenergy $24,445-464$.

Morsy, M.I.N. (2011).Properties of Rice Straw Cementitious Composite.Published PhDThesis .Department of Civil Engineering and Geodesy.TecnischeUniversitätDarmstadt. GermanyP: 62:64. Available at:http://tuprints.ulb.tudarmstadt.de/2847/1/Dissertation_Morsy_20 11.pdf

Nalladurai, N. R., and Morey V.(2006). Factors Affecting Strength and Durability of Densified ProductsPaper number 066077, ASAE Annual Meeting, American Society of Agricultural and Biological Engineers, St. Joseph, Michigan. .

doi: $10.13031 / 2013.21754$

Patabang, D. (2012). Thermal characteristics and variation of rice husk briquettes with adhesivematerials:KarakteristikTermalBriketArangSekamPadideng anVariasiBahanPerekat: JurnalMekanikal. Vol 3 (2): 286- 293. 
Pryor, M. (1988).The International Briquetting Annual Report. Swedish International Development Agency (SIDA). Sweden.

Shigley,J., Mischke C. R., Brown Jr. T. H. (2004). Standard Handbook of Machine Design, 3rd Edition.McGraw-Hill Professional, ISBN13: 063-9785511038 ISBN-10: 0071441646, 1200 pages.

Yaman, S., Sahan M.,Haykiri-Acma H., Sesen, K.,Kucukbayrak, S.(2001). Fuel Briquettes from Biomass-Lignite Blends. Fuel Processing Technology, 72: 1-8.

Wessapan, T., T. N. Somsuk and T. Borirak (2010).Design and Development of a Compact Screw-Press Biomass Briquetting Machine for Productivity Improvement and Cost Reduction. The First TSME International Conference on Mechanical Engineering 20-22 October, UbonRatchathani. Thailand..

Zhang, Y., A.E. Ghaly and B. Li (2012). Physical properties of rice residues as affected by variety and climatic and cultivation conditions in three continents. Am. J. Applied Sci., 9: 1757-1768.

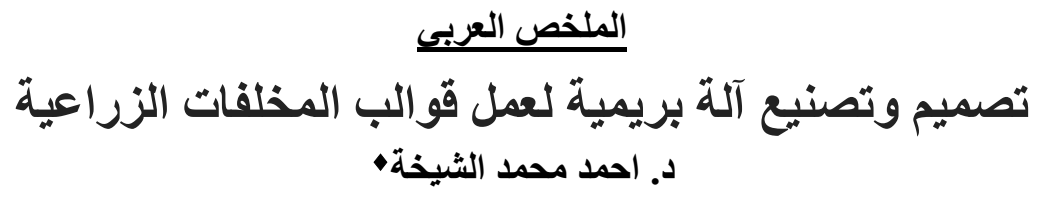

تم تصميم وتصنيع آلة عمل قو الب المخلفات الزر اعية البريمية و اختبار ها مع اثثين من المخلفات

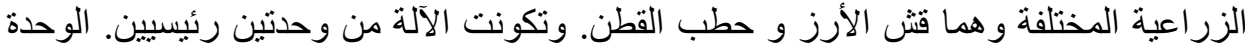

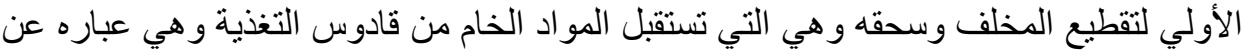

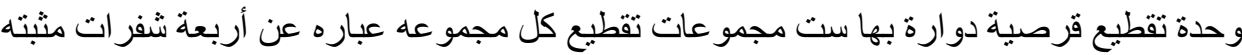

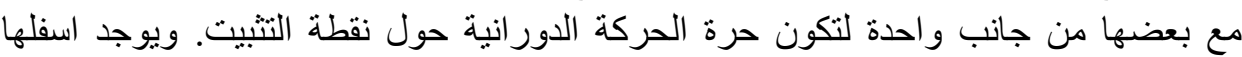
قرص مثقب يسمح بمرور أطوال قطع المخلفات المطلوبة.

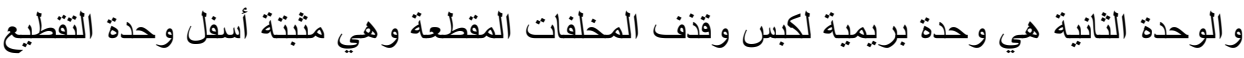

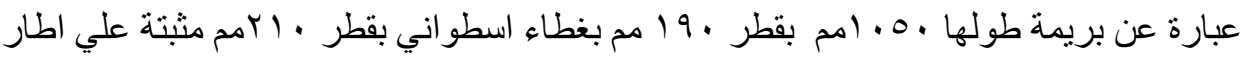

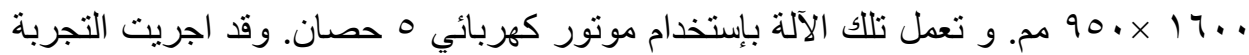

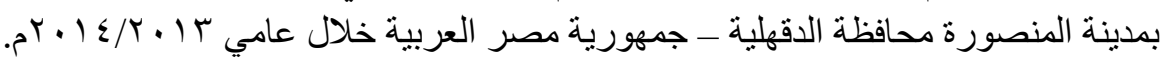
•مدرس الهندسة الزراعية ـ كلية الزراعة - جامعةدمياط 
وقد تم اختبار الآلة مع تثبيت نسبة الانضغاط ، فتحة الخروج ، و حجم البريمة. و كانت متغيرات

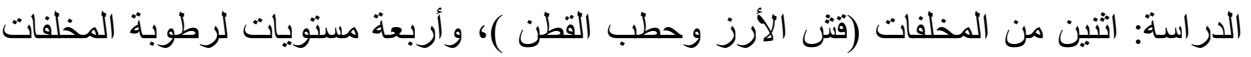

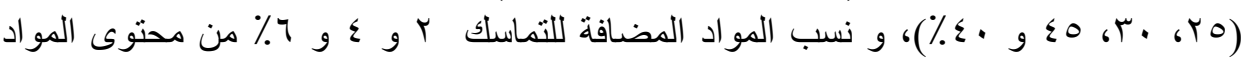
الخام. وتم تعديل نسب الرطوبة لتكون على المستوى المطلوب قبل البدء في عملية القولبة. وتم اختبار صلابة وكثافة القو الب الناتجة مع مختلف نسب الرطونة الرطوبة.

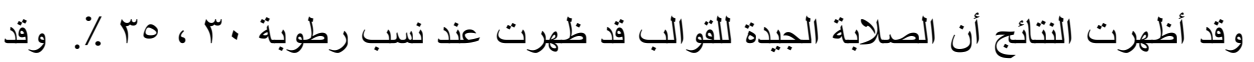

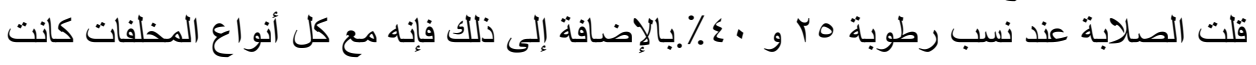

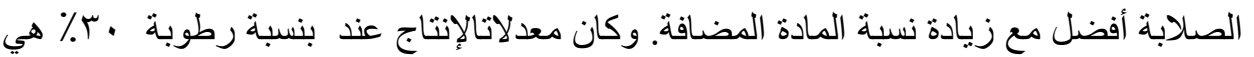

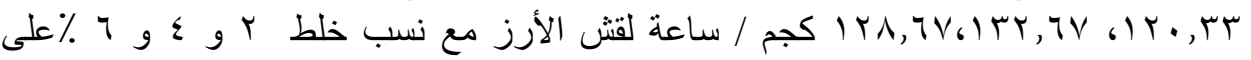

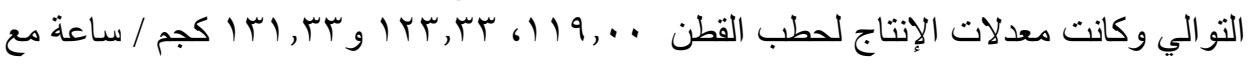

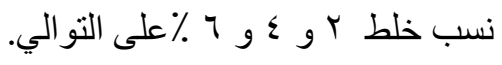

ومع ذلك فإن محتويات الرطوبة هب و ـء ـ تؤدي إلى انخفاض معدل الإنتاج. وزيادة نسب الخلط تؤدي الي كثافة أعلي لكل من فش الأرز وحطب القطن وخاصة مع ارتب الفاع نسبة الرطوبة. 